\title{
基于如何构建浓郁校园文化增强德育整体效能探讨
}

\author{
王小平 刘永松
}

陕西省镇安中学

DOI:10.32629/jief.v2i9.1707

[摘 要] 校园德育工作的开展关系到学生的全面发展, 新时期在有效促进教育改革的社会背景下, 应该结合校园文化的建设渗透德育教育思 想, 促进学校德育教育质量得到明显的提升。在本次研究中结合地方德育文化特色, 针对校园文化建设中增强德育整体效能的措施进行了探 究, 仅供参考。

[关键词] 校园文化; 德育工作; 教育改革

中图分类号：D422.6 文献标识码：A

德育是立德树人根本任务得到贯彻落实背景下需要重点关注的问 题, 只有突出学校德育特色, 积极开发德育活动, 实现过程育人的目标, 才能发挥德育工作的效果, 从 “仰圣笃行” “立志、勤学、改过、责善” 角度对学生实施积极的教育指导, 真正构建德育工作体系, 在良好的文 化熏陶中形成健康的德育教育场域环境, 维护学生全面发展。鉴于此, 应该注意从校园文化氛围的营造角度, 针对德育教育活动的综合效果进 行探究, 为学校教育工作和人才培养工作的科学开展奠定坚实的基础。

\section{1 校园文化环境的德育功能}

校园文化是学校德育工作中极其重要的构成元素, 校园文化环境的 构建能从不同的角度对学生实施德育教育引导, 深化学生的思想认识, 促进学生健康成长。一般情况下, 校园文化环境涉及到学生的学习和活 动场所、师生群体的价值观念、校训、校风和教学活动以及师生群体的 行为准则和思维方式等, 校园文化环境在学生群体中实现全面覆盖, 并 能从不同的角度对学生学习和成长产生相应的影响, 具有极其重要的价 值, 一般情况下, 校园文化环境德育功能主要从文化熏陶功能、行为规 范和约束功能、情感激励功能等角度得到体现, 因此在校园文化建设实 践中为了最大限度的提升德育整体效能, 就要结合校园文化的主要德育 功能进行分析, 促进完善德育教育体系的构建, 进而优化校园文化环境 建设综合发展成效, 为学生营造相对积极健康的成长空间。

\section{2 构建浓郁校园文化增强德育整体效能的措施}

为了能充分发挥校园文化环境的影响作用维护学生健康成长, 在教 育实践中要注意选取合适的切入点进行探究, 构建完善的教育体系, 保 障德育功能得到全面系统的发挥, 为学生思想道德素质的提高和精神认 知的逐步强化做出积极有效的指导。下面就结合学校文化环境的构建, 针对德育整体效能的提升进行分析, 确保能在先进文化教育的作用下, 维护学生身心健康发展。

2.1 创新校园物质文化, 发挥环境熏陶作用

校园物质文化是校园文化体系中最直观、影响最为明显的文化内容, 教师按照德育教学要求对校园物质文化进行建设和完善, 能营造积极健 康的德育空间, 发挥环境熏陶作用深化学生的思想认识, 有效促进学生 实现身心健康发展的目标。

如在学校物质文化环境的建设方面, 在学校校训石、文化墙、宣传 栏及建筑物命名上就可以引入我国传统文化体系中君子文化的主题思 想, 从君子当浩然正气、君子当博学壼智、君子当志趣高雅等角度对宣 传栏进行布置, 重点宣传 “君子博学于文, 约之以礼” “在邦无怨, 在家无
怨” “克己复理为仁” “君子成人之美, 不成人之恶” “君子道者三, 仁者不 忧, 智者不惑, 勇者不惧” 等方面的文化教育和指导, 培养学生形成君子 品格, 健全学生人格。如此就能发挥校园物质文化环境的重要作用, 促 进学校德育效能的不断提升, 为学生健康成长做出积极有效的指引。

2.2 坚持正确與论导向, 对学生实施情感激励

在对校园物质文化教育进行优化的基础上, 教师要注意坚持正确的 舆论导向, 创新精神文化教育, 以高尚的精神对学生实施文化感召和情 感激励, 进而在有效教育指导的作用下深化学生的思想认识, 促进学生 逐步形成正确的人生观和价值观, 为学生全面发展奠定良好的德育基础。

如在校园广播和校园网站布置方面, 学校可以将新型冠状病毒肺炎 疫情期间各行各业工作者爱岗敬业做出巨大贡献的情况作为主题，开展 文化宣传和教育活动, 以典型的人物故事在校园中形成正确的文化导向, 对学生实施情感激励。在此基础上, 为了实现对文化育人教育作用的升 华, 教师导入习近平总书记关于继承革命传统, 发扬奉献精神的重要论 述, 在融合时代精神和传统文化精神的基础上对学生实施教育指导, 使 青年学生能坚定理想信念, 能对个人社会责任和历史使命形成全新的认 识, 能按照习近平总书记的重要指示积极弘扬奉献精神和牺牲精神, 自 强不息努力奋斗。在正确與论导向的作用下, 提高学生思想认识水平, 真正发挥校园文化的作用, 循序渐进提升学生群体的精神境界, 为学生 未来逐渐实现全面发展的目标指明方向。

\section{3 结语}

综上所述, 校园文化对于德育工作的开展和创新产生积极的影响, 新时期基于立德树人根本任务的要求, 在全方位推进德育教育改革的社 会背景下, 选取学校校园文化建设作为切入点, 在校园文化建设实践中 引入德育教育元素, 能最大限度的凸显德育教育的综合影响力, 为学生 创造良好的生活和成长空间, 促进学生全面发展, 真正将学生培养成为 能推动中华民族伟大复兴事业发展的高素质人才。

\section{[参考文献]}

[1]张慧钧.新时期校园文化在高校德育中的实践体会 [J].智库时 代,2020(11):199-200.

[2]初帅奇.基于校园文化建设的高职德育教育新模式构建策略 [J]. 科技资讯,2020,18(06):93-94.

[3]方珂珂.校园文化建设与学校德育研究[J].时代报告,2017(20).

[4]李洪涛,赵国栋.丰富绩效考核内涵提升基层团队整体效能的思考 [J].现代金融,2018,No.423(05):50-51. 